\title{
The Extracellular Enzymes of Coniophora cerebella
}

\author{
BY N. J. KING \\ Forest Products Research Laboratory, Princes Risborough, Bucks.
}

(Received 22 February 1966)

\begin{abstract}
1. The extracellular enzymes present in the culture filtrates of Coniophora cerebella grown on various carbohydrate carbon sources were investigated. Enzymes that degraded cellulose derivatives, hemicellulose fractions, starch, laminarin, pectin and several oligosaccharides were detected. 2. All the polysaccharidedegrading activities were adaptive except for that acting on laminarin. 3. The culture filtrates degraded native cellulose to only a very limited extent. 4. The hemicellulase activity included enzymes acting on all the major components of wood hemicellulose. 5. The main starch-degrading enzyme was a glucoamylase. 6. Laminarin-degrading activity was produced when cellulose, hemicellulose or starch was used as carbon source for the fungus and it may be involved in the re-utilization of hyphal carbon or of a reserve polysaccharide synthesized during active growth of the organism.
\end{abstract}

Fungi able to use wood as a carbon source form a relatively small and specialized group that may be subdivided into brown-rot, white-rot or soft-rot organisms according to the type of decay they cause. Brown-rot fungi degrade only the polysaccharide fraction of wood, whereas the white-rot and soft-rot organisms utilize both the lignin and the polysaccharide fractions. Soft-rot is distinct in that the fungal hyphae are commonly found only in cylindrical cavities formed within the secondary wall of the wood cells by enzymic erosion. Such cavities are not a consistent feature of white-rots or brown-rots, the hyphae in these types of decay usually occurring in the cell lumen.

Coniophora cerebella (Pers.) Duby is the commonest wood-destroying fungus found in Britain. Characteristically, it attacks timber structures in damp situations, causing a typical brown-rot. The fungus penetrates the substance of the wood through vessels and ray cells and enters the fibre cells by means of bore-holes or the natural pit structures. The decay then proceeds from the cell lumen outwards, the heavily lignified middle lamella being attacked last (Rypáček, 1960). The structural polysaccharides of the wood cell wall are extensively degraded (Apenitis, Erdtman \& Leopold, 1951; Seifert, 1962) and the wood rapidly loses its strength (Armstrong \& Savory, 1959; Kubiak \& Kerner, 1963).

Extracellular enzymes secreted by the advancing hyphae are generally thought to be responsible for the hydrolysis of the cell-wall polysaccharides. However, considering the economic importance of timber decay, very little is known of the fungal degradation of wood at the enzymic level. Early attempts to verify the presence of extracellular enzymes (e.g. Lutz, 1930; Bose \& Sarkar, 1937) were confined to detecting activities in culture filtrates, often of ill-defined origin, acting on poorly characterized substrates. Most of the more recent interest in wood-destroying fungi has centred on their cellulolytic ability and several workers have reported the isolation of relatively pure enzymes (e.g. Higa, O'Neill \& Jennison, 1956; Sison, Schubert \& Nord, 1957, 1958; Petterson \& Porath, 1963) and described their action on various substrates. Lyr $(1959 a, b, c, 1960,1962,1963 a, b)$ has studied the induction of the extracellular enzymes of a number of wood-destroying fungi, including C. cerebella, grown on liquid media. Amylase, mannanase, pectinase, xylanase and cellulase were found, their production being greatly stimulated by incorporating the respective substrates in the culture medium. Apart from this work of Lyr, little interest has been shown in the hemicellulosedegrading enzymes of brown-rot fungi, probably because of the lack of suitably characterized substrates. In the present paper, the induction and characterization of the extracellular polysaccharide-degrading enzymes of a single organism, C. cerebella, are described.

\section{METHODS AND MATERIALS}

Organism. The organism used throughout this work was C. cerebella, F.P.R.L. culture no. 11E. This is a highly active strain producing rapid and extensive weight losses in the standard decay tests. 
The fungus was grown successfully in stationary and shake cultures on media consisting of a suitable carbon source and a basal salts solution containing (per l.) $\mathrm{KH}_{2} \mathrm{PO}_{4}$ (1.5 g.), $\mathrm{MgSO}_{4}, 7 \mathrm{H}_{2} \mathrm{O}$ (0.5 g.), $\mathrm{NH}_{4} \mathrm{NO}_{3}(0.7 \mathrm{~g}),. \mathrm{CaCl}_{2}$ (0.1 g.), thiamine hydrochloride (1.0 mg.), $\mathrm{H}_{3} \mathrm{BO}_{3}(570 \mu \mathrm{g}$.$) ,$ $\mathrm{FeCl}_{3}\left(145 \mu \mathrm{g}\right.$.), $\mathrm{CoCl}_{2}, 6 \mathrm{H}_{2} \mathrm{O}$ (40 $\mu \mathrm{g}$.), $\mathrm{CuSO}_{4}, 5 \mathrm{H}_{2} \mathrm{O}$ (60 $\mu \mathrm{g}$.), $\mathrm{MnCl}_{2}, 4 \mathrm{H}_{2} \mathrm{O}\left(30 \mu \mathrm{g}\right.$.), $\left(\mathrm{NH}_{4}\right)_{6} \mathrm{Mo}_{7} \mathrm{O}_{24}, 4 \mathrm{H}_{2} \mathrm{O}(20 \mu \mathrm{g}$.) and $\mathrm{ZnSO}_{4}, 7 \mathrm{H}_{2} \mathrm{O}$ (310 $\mu \mathrm{g}$.) dissolved in water and with the $\mathrm{pH}$ adjusted to $5 \cdot 0-5 \cdot 5$ with $4 \mathrm{~N}-\mathrm{NaOH}$. This medium (medium A) was found to be satisfactory for stationary cultures, but to counter the rapid build-up of acidity in shake cultures additional buffering capacity was necessary. Medium $B$ was therefore developed in which the $\mathrm{KH}_{2} \mathrm{PO}_{4}$ content was increased (to $10 \mathrm{~g}$./ $/$.) and $\mathrm{NH}_{4} \mathrm{NO}_{3}$ was replaced by asparagine (1 g./1.).

Stationary cultures. Portions $(80 \mathrm{ml}$.) of medium A were dispensed into $250 \mathrm{ml}$. flasks that had a pad of glass wool in the bottom projecting above the liquid surface in places.

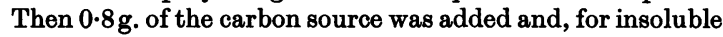
materials, the flask shaken to disperse it over the bottom of the flask and through the glass-wool pad. The flasks and contents were autoclaved, cooled and inoculated with a $4 \mathrm{~mm}$. disk cut from near the growing edge of a $2 \%$ malt-agar culture. The disk was placed on the glass wool at a point where it emerged from the liquid. Growth was slow, 4 weeks at least being required for good enzyme production.

Shake cultures. These were prepared with $80 \mathrm{ml}$. of medium $B$ and $0 \cdot 8 \mathrm{~g}$. of the carbon source in a $250 \mathrm{ml}$. conical flask. The inoculum in this case was a dispersion of mycelium in the basic medium. The orbital shaking-machine (L H Engineering Co. Ltd., Bells Hill, Stoke Poges, Bucks.) had a throw of $2 \mathrm{~cm}$. and was operated at about $100 \mathrm{rev} . / \mathrm{min}$. Optimum enzyme concentration was achieved more rapidly under these conditions than with stationary cultures and harvesting was sometimes possible after 2 weeks.

Stationary and shake cultures were incubated at $25^{\circ}$. The crude enzyme solutions were obtained by filtering the culture liquors through a no. 3 fritted-glass filter and adjusting the $\mathrm{pH}$ of the filtrate to 5 with $\mathrm{N}-\mathrm{NaOH}$. The solutions were stored frozen unless used immediately.

Carbon sources and substrates. Norway-spruce sawdust was sieved to pass 100 mesh.

$\alpha$-Cellulose was prepared from Norway-spruce sawdust (40-80 mesh) by extracting with cold acetone and hot water and then delignifying with acidified chlorite (Wise, Murphy \& D'Addieco, 1946); the resulting holocellulose was extracted, in turn, with dimethyl sulphoxide, hot water, $5 \%(w / v) \mathrm{KOH}, 24 \%$ (w/v) $\mathrm{KOH}$ containing $4 \%(\mathrm{w} / \mathrm{v})$ of $\mathrm{H}_{3} \mathrm{BO}_{3}$ and hot water, and the residual $\alpha$-cellulose was dried with ethanol and ether. The alkaline extractions were carried out under $\mathrm{N}_{2}$.

Reconstituted or partially degraded cellulose was prepared from standard chromatography-grade cellulose powder by dispersing in $70 \%(v / v) \mathrm{H}_{2} \mathrm{SO}_{4}(5 \mathrm{~g}$. of cellulose/ $100 \mathrm{ml}$. of acid) at $0^{\circ}$ and leaving it at room temperature for $2 \mathrm{hr}$. The solution was poured into a large volume of icewater and neutralized. Coagulation of the precipitate was improved by freezing and thawing. The precipitate was dispersed in water, dialysed against water and then freezedried. A suspension of this freeze-dried powder in buffer remained dispersed for several days.

Sodium CM-cellulose, salicin and cellobiose were obtained from British Drug Houses Ltd., Poole, Dorset. The cellobiose was freed of traces of glucose by charcoal-column chromatography (Jermyn, 1957). Gentiobiose was purchased from Koch-Light Laboratories Ltd., Colnbrook, Bucks.

Hemicellulose fractions were prepared from spruce holocellulose. A water-soluble fraction was extracted by dimethyl sulphoxide and used as substrate in the hemicellulase assay. Paper chromatography of acid hydrolysates of this material showed that it contained mainly glucose, mannose and xylose residues and was presumably a mixture of partly acetylated xylan and glucomannan. Other fractions were a relatively pure glucomannan and a xylan free of glucomannan obtained by selective extraction and precipitation (Jones, Wise \& Jappe, 1956; Meier, 1958); both were insoluble in water and were ground and used as suspensions. The hemicellulose used as a carbon source and referred to in Table 1 was a crude xylan fraction containing appreciable amounts of glucomannan.

Arabinogalactan was prepared from European-larch sawdust by leaching with hot water and the water-soluble polysaccharide was precipitated with ethanol.

Pectin (apple pectin; British Drug Houses Ltd.) was purified by cycling through calcium pectate twice, with ammonium oxalate as regenerating agent, and then dialysed and freeze-dried. The starch used was either soluble starch (A.R. grade; British Drug Houses Ltd.) or a waxy maize starch (from Professor D. J. Manners) that was almost pure amylopectin. Maltose was purchased from British Drug Houses Ltd. Malt extract (Oxoid Ltd., London, S.E. 1) is frequently used as a constituent of mycological culture media. As well as nitrogen compounds, vitamins and trace nutrients, it is rich in maltose, dextrin and other starch-degradation products. Laminarin was purchased from Liverpool Borax Co. Ltd., Liverpool 3.

Analytical methods. Glucose was estimated by the glucoseoxidase method of Huggett \& Nixon (1957) with the tris buffer recommended by Dahlquist (1961). Under these conditions cellobiose, gentiobiose, maltose and salicin did not interfere. Glucose oxidase, peroxidase and $o$-dianisidine were obtained from British Drug Houses Ltd. Protein was estimated by the method of Lowry, Rosebrough, Farr \& Randall (1951) after precipitation with $5 \%(w / v)$ trichloroacetic acid. The method was standardized with bovine serum albumin (crystalline; British Drug Houses Ltd.).

Iodine staining. Starch solution or digest of starch solution (2 mg./ml.; $1 \mathrm{ml}$.) and iodine-iodide solution $(0 \cdot 1 \mathrm{mg}$. of $\mathrm{I}_{2}$ and $1.0 \mathrm{mg}$. of $\mathrm{KI} / \mathrm{ml}$.; $1 \mathrm{ml}$.) were mixed and diluted to $50 \mathrm{ml}$. with water. The absorption of the complex was measured in $1 \mathrm{~cm}$. cells in a spectrophotometer against a reagent blank containing no starch or digest of starch solution.

Enzyme assay. A $2 \mathrm{ml}$. portion of substrate solution $(0.1 \%$ in $0.1 \mathrm{~N}$-acetic acid adjusted to $\mathrm{pH} 5$ with $4 \mathrm{~N}-\mathrm{NaOH})$ and $0.1 \mathrm{ml}$. of the enzyme solution were incubated in a water bath at $40^{\circ}$ for $1 \mathrm{hr}$. The reducing sugar produced was estimated on the total digest by the Nelson-Somogyi method (Nelson, 1944; Somogyi, 1952) with $0.1 \mathrm{ml}$. of boiled enzyme $\left(10 \mathrm{~min}\right.$. at $\left.100^{\circ}\right)$ in the blank. The results were recorded in terms of glucose equivalent, i.e. the amount of glucose giving the same colour yield. The relationships between glucose equivalent and relative enzyme concentration followed the curves shown in Fig. 1. These relationships were sufficiently reliable for the comparison of enzyme concentrations in culture filtrates and were used in determining the best time to harvest the various cultures. With 


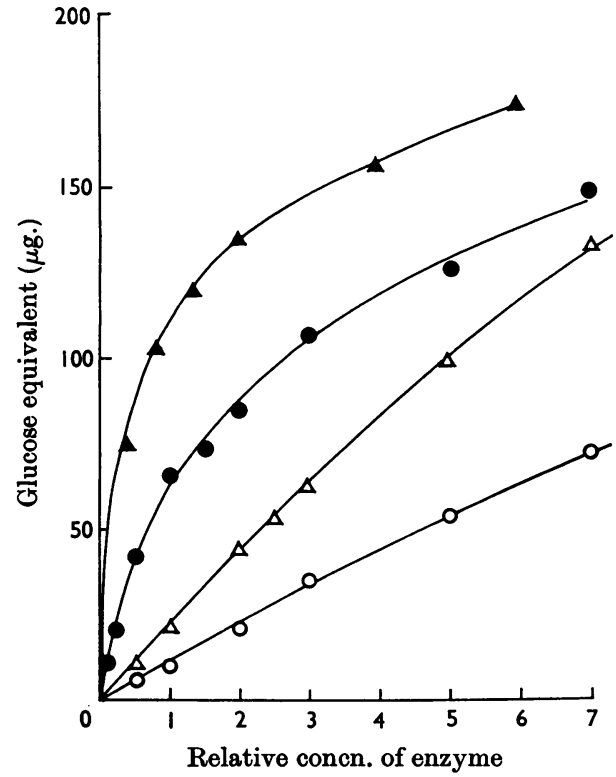

Fig. 1. Relationship of glucose equivalent to enzyme concentration. The reaction mixture $(2 \cdot 1 \mathrm{ml}$.) contained substrate (2mg.), 0.4 M-acetate buffer, pH5.0 (0.5 ml.), and different proportions of culture filtrate and water. Glucose equivalent was estimated as described in the text. cellulose; $\boldsymbol{\Delta}$, water-soluble hemicellulose; $O$, soluble starch; $\Delta$, laminarin. The culture filtrate used in the starch and laminarin experiments was diluted 1:10 before use.

hemicellulase, amylase and laminarinase produced by cultures containing strong inducers of these activities, it was often necessary to dilute the filtrates before comparing them.

A straight-line relationship existed between the initial rate of glucose-equivalent production and the relative enzyme concentration (Fig. 2) but measurement of an initial rate was too time-consuming for a routine screening test.

Enzyme digests. Standard digests consisted of substrate solution ( $2 \mathrm{mg} . / \mathrm{ml}$; $5 \mathrm{ml}$.), enzyme solution ( $1 \mathrm{ml}$.$) and$ $0 \cdot 1 \mathrm{~m}$-acetate buffer, $\mathrm{pH} 5$, to $10 \mathrm{ml}$. Incubation was carried out at $40^{\circ}$ with toluene as preservative. The products of digestion were separated by descending paper chromatography with the following solvent systems: $A$, for mono- and di-saccharides: ethyl acetate-pyridine-acetic acid-water (5:5:1:3, by vol.); $B$, for oligosaccharides: propan-1-olwater $(2: 1, v / v)$. The separated sugars were detected by the aniline phthalate reagent of Wilson (1959) or the alkaline$\mathrm{AgNO}_{3}$ reagent of Trevelyan, Procter \& Harrison (1950), with a thiosulphate wash solution $\left[10 \%(w / v) \mathrm{Na}_{2} \mathrm{~S}_{2} \mathrm{O}_{3}\right.$ in aq. $50 \%(\mathrm{v} / \mathrm{v})$ ethanol] to diminish the background colour.

Enzyme nomenclature. Cellulase activity denotes the formation of reducing sugars from polymeric cellulosic materials ( $\alpha$-cellulose, cellulose powder, reconstituted cellulose or CM-cellulose). This is not intended to imply that the same enzyme or combination of enzymes was involved in the hydrolysis of all these substrates, but

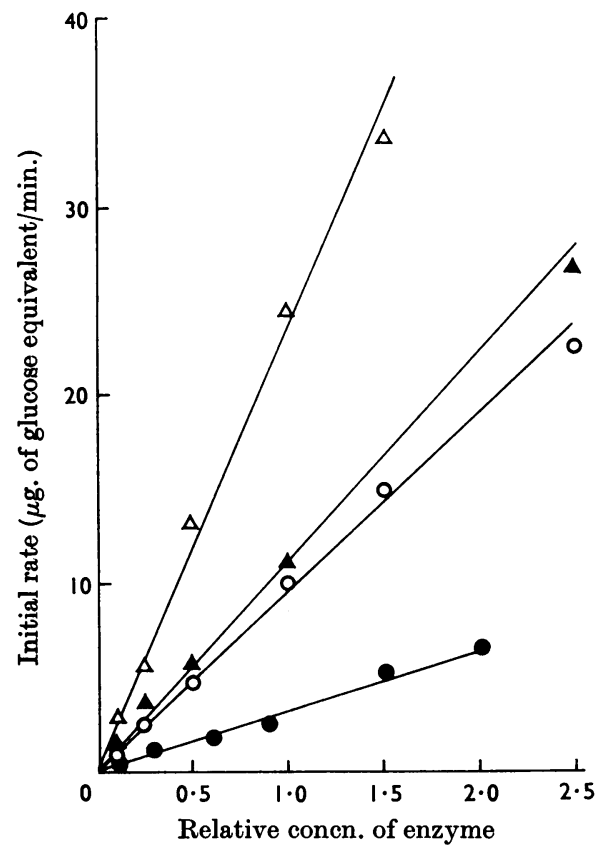

Fig. 2. Relationship of initial rate of glucose-equivalent production to enzyme concentration. The initial rate of glucose-equivalent production was measured by determining at timed intervals the glucose equivalent of digests (total volume $2 \cdot 1 \mathrm{ml}$.) containing substrate $(2 \mathrm{mg}$.), $0.4 \mathrm{M}$-acetate buffer, pH $5.0(0.5 \mathrm{ml}$.), and different proportions of culture filtrate and water. Curves were constructed of glucoseequivalent production against time and tangents to these curves, passing through zero time, gave the initial rates. -, CM-cellulose; $\Delta$, water-soluble hemicellulose; $\bigcirc$, soluble starch; $\triangle$, laminarin.

simply that the assay method employed may not have distinguished differences in activity and it is therefore convenient to use the term 'cellulase' to describe all such activities. Hemicellulase is a general term used to describe any activity resulting in the formation of reducing sugars from a component or components of the hemicellulose fraction of wood. Similarly, amylase, laminarinase and pectinase refer to activities involved in the production of reducing sugars from starch, laminarin and pectic acid respectively.

\section{RESULTS}

Growth of the fungus and enzyme production. Table 1 lists the enzyme activities detected in the culture filtrates and shows the effects of carbon source and culture conditions on the production of some of these enzymes. With the exception of laminarinase $[\beta-(1 \rightarrow 3)$-glucanase] all the enzymes acting on polysaccharides were adaptive. There was little difference in enzyme production between stationary and shake cultures, as measured by the 


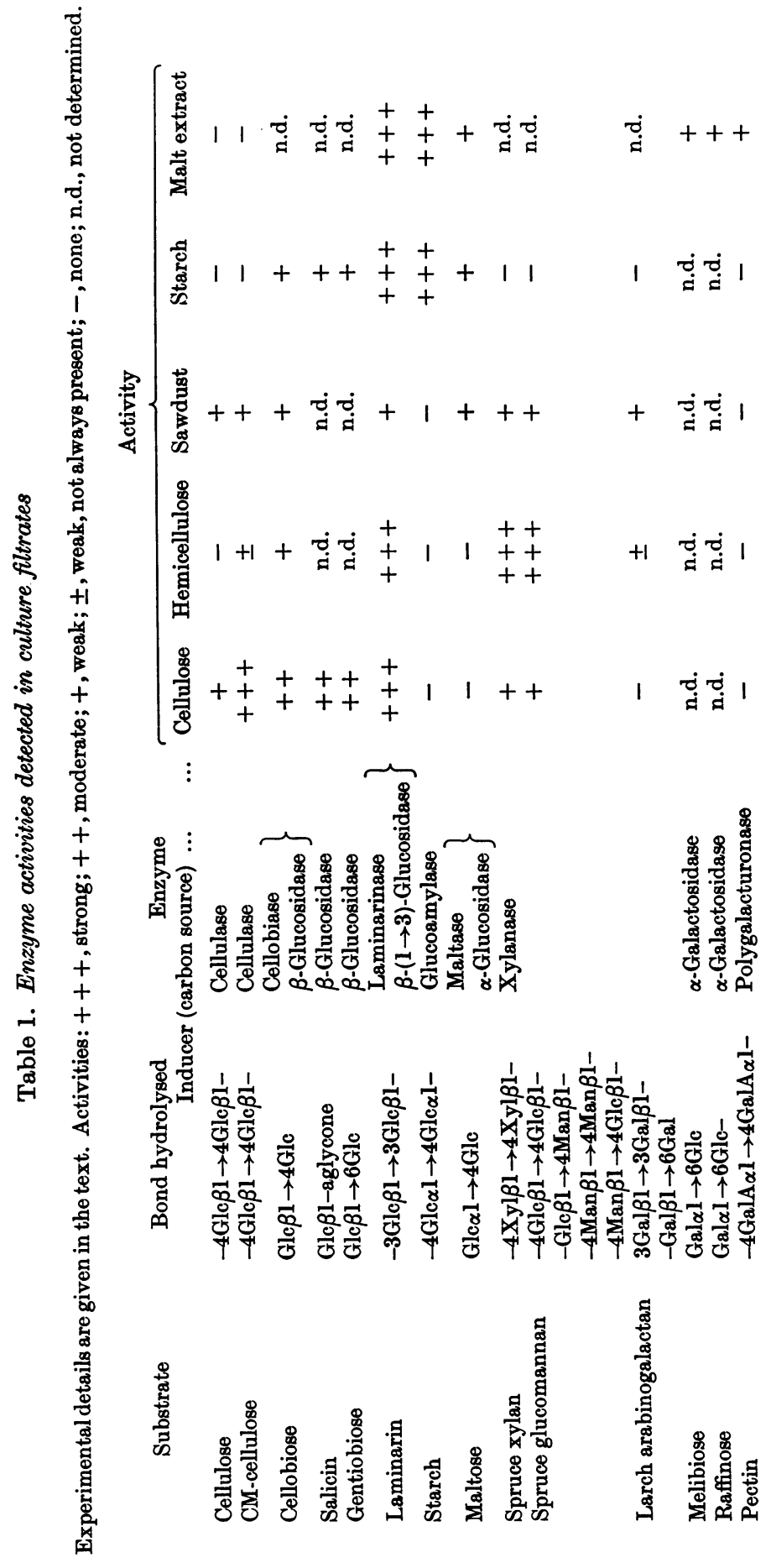


standard assay procedure, except that growth of the fungus and production of enzymes was much slower with the stationary cultures. Addition of yeast extract did not increase enzyme yields, and maximum fungal growth and enzyme production occurred as readily with spruce $\alpha$-cellulose as sole carbon source as on richer media. However, shake cultures with cellulose as carbon source gradually became less active as successive subcultures were made and after six such transfers a fresh culture was prepared from stocks maintained on malt-agar or on sawdust.

Acid production was a feature of the growth of the fungus and the final $\mathrm{pH}$ was generally between 2 and 3 in medium $A$ and about 4 in medium $B$.

Fig. 3 shows the production of cellulase and hemicellulase during the growth of a stationary

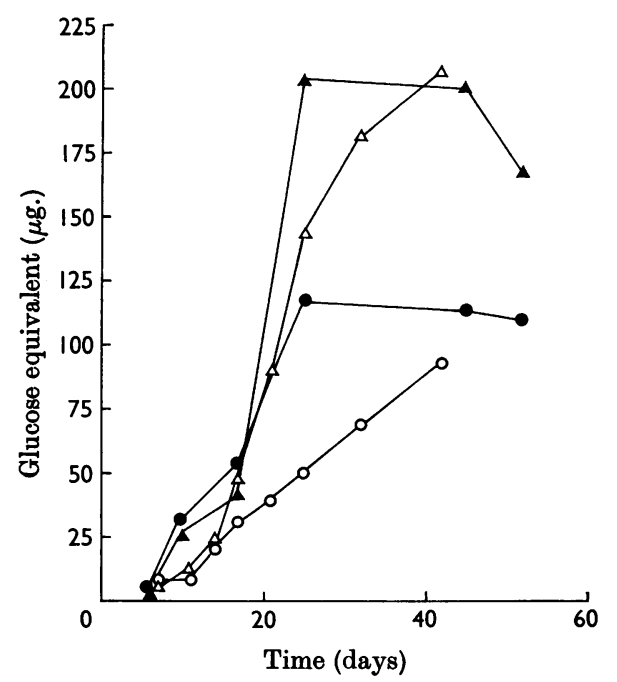

Fig. 3. Production of cellulase and hemicellulase by stationary and shake cultures. $O$, Cellulase, and $\Delta$, hemicellulase, produced in stationary culture with spruce sawdust as carbon source; $\bullet$, cellulase, and $\boldsymbol{\Delta}$, hemicellulase, in shake culture with spruce $\alpha$-cellulose as carbon source. culture on spruce sawdust. Neither activity was produced in preference to the other during the experiment. In addition, the production of cellulase and hemicellulase by shake cultures grown on $\alpha$ cellulose is also shown in Fig. 3. A maximum activity occurred at about 20 days and thereafter fell off. The fall in enzyme activity was accompanied by a 'staling' of the culture and autolysis was visible on microscopic examination.

The protein contents of representative culture filtrates are shown in Table 2.

Properties of the enzymes present in the culture filtrate. The effect of $\mathrm{pH}$ on enzyme activity was studied by varying the $\mathrm{pH}$ of the acetate buffer in the standard assay procedure. The results are shown

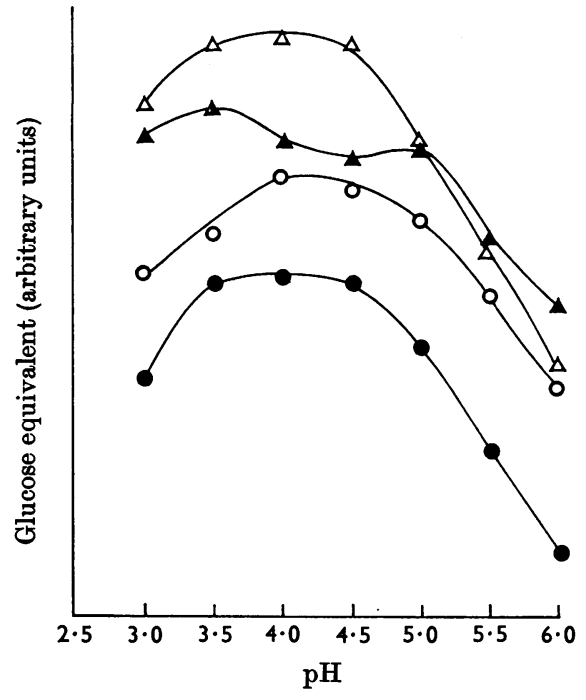

Fig. 4. Effect of pH on enzyme activity. Reaction mixtures contained substrate ( $2 \mathrm{mg}$.), $0 \cdot 1 \mathrm{~m}$-acetate buffer $(2.0 \mathrm{ml}$.) and enzyme solution $(0 \cdot 1 \mathrm{ml}$.). C, Cellulase (acting on reconstituted cellulose); $\boldsymbol{\Delta}$, hemicellulase; $O$, amylase (acting on soluble starch); $\Delta$, laminarinase. The culture filtrate used in the starch and laminarin experiments was diluted $1: 10$.

Table 2. Protein contents of representative culture filtrates

Experimental details are given in the text.

$\begin{array}{lclc}\text { Conditions of growth } & \begin{array}{c}\text { Time of growth } \\ \text { (weeks) }\end{array} & \text { Carbon source } & \begin{array}{c}\text { Protein content } \\ (\mu \mathrm{g} . / \mathrm{ml} .)\end{array} \\ \text { Stationary, medium A } & 6 & \alpha \text {-Cellulose } & 40 \\ \text { Stationary, medium A } & 16 & \alpha \text {-Cellulose } & 130 \\ \text { Stationary, medium A } & 6 & \text { Sawdust } & 10 \\ \text { Shake, medium B } & 3 & \alpha \text {-Cellulose } & 120 \\ \text { Shake, medium B } & 3 & \text { Hemicellulose } & 190 \\ \text { Shake, medium B } & 3 & \text { Starch } & 35 \\ \text { Shake, medium B } & 3 & \text { Sawdust } & 10\end{array}$


in Fig. 4. The optimum $\mathrm{pH}$ ranges for cellulase, hemicellulase, amylase and laminarinase were $3 \cdot 5-4 \cdot 0,3 \cdot 0-5 \cdot 0,4 \cdot 0-4 \cdot 5$ and $3 \cdot 5-5 \cdot 0$ respectively.

Two temperature effects were studied. By carrying out the standard assay procedure at temperatures between $25^{\circ}$ and $65^{\circ}$, the optimum temperatures for cellulase, hemicellulase, amylase and laminarinase activities were found to be $50^{\circ}, 50^{\circ}$, $45^{\circ}$ and $45^{\circ}$ respectively. By holding the enzyme solution for $10 \mathrm{~min}$. at temperatures between $45^{\circ}$ and $90^{\circ}$ and then cooling and carrying out the standard assay procedure at $40^{\circ}$, the thermal stabilities of the activities were compared. The results are shown in Fig. 5.

Degradation of substrates. Cellulose. The culture filtrate produced very small weight losses when incubated with spruce sawdust, spruce $\alpha$-cellulose or cellulose powder (chromatography grade). Thus when samples $(100 \mathrm{mg}$.) of these substrates were incubated at $40^{\circ}$ with culture filtrate $(5 \mathrm{ml}$.; adjusted to $\mathrm{pH} 5$ with $\mathrm{N}$-sodium hydroxide) and toluene for 2 weeks, the weight losses were $2,0.5$ and $1 \%$ for spruce sawdust, spruce $\alpha$-cellulose and cellulose powder respectively. When the culture filtrate was replaced with fresh solution every $48 \mathrm{hr}$. during the 2 -week incubation period, the weight losses increased to 6,1 and $2.5 \%$ respectively, but little further increase was noted with longer exposures. The products of cellulose hydrolysis were largely oligosaccharides with relatively little glucose.

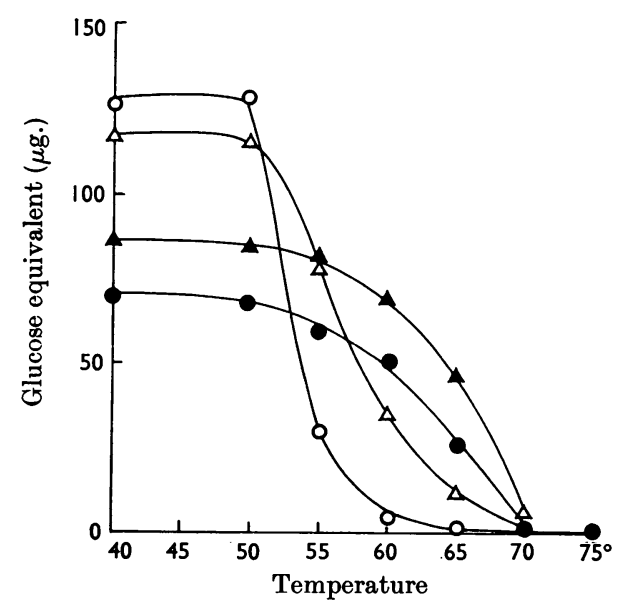

Fig. 5. Effect of heating on enzyme activity. Reaction mixtures contained substrate ( $2 \mathrm{mg}$.), $0 \cdot 1 \mathrm{M}$-acetate buffer, pH5.0 (2.0 ml.), and $0.1 \mathrm{ml}$. of an enzyme solution that had previously been held at the temperature shown for $10 \mathrm{~min}$. Glucose equivalent was then estimated by the standard assay procedure described in the text. $\bullet$, Cellulase; $\boldsymbol{\Delta}$, hemicellulase; $O$, amylase; $\Delta$, laminarinase. The culture filtrate used in the starch and laminarin experiments was diluted $1: 10$.
Reconstituted cellulose. This was completely degraded, the products again being largely oligosaccharides. The major cellulolytic activity in the culture filtrate therefore seems to operate in a random manner along the cellulose chains available to it, the reconstituted cellulose being completely accessible whereas the more native forms of cellulose have very limited accessibility.

CM-cellulose. This was rapidly hydrolysed but the presence of substituent groups in the molecule made it difficult to draw conclusions on the nature of this reaction from the products formed. However, it is likely that this too was a random degradation.

Salicin, gentiobiose and cellobiose. The initial rates of hydrolysis of salicin, gentiobiose and cellobiose under the same conditions $(0.1 \mathrm{~m}$-mole of substrate; $2 \mathrm{ml}$. of cellulose-grown culture filtrate; $0 \cdot 1 \mathrm{M}$-acetate buffer, $\mathrm{pH} 5 \cdot 0$, to $25 \mathrm{ml}$.) were in the proportions $1 \cdot 5: 1 \cdot 4: 1 \cdot 0$, indicating that the $\beta$ glucosidase activity did not represent residual activity of the cellulase on $\beta$-glucosides. That the fungus could produce $\beta$-glucosidase independently of cellulolytic activity was also shown by the weak activity of starch-grown culture filtrates on salicin, gentiobiose and cellobiose; such culture filtrates had no activity on CM-cellulose.

Hemicellulose. Table 1 shows that the culture filtrates contained a mixutre of enzymes active on the hemicellulose fractions of wood. Thus spruce xylan and glucomannan, larch arabinogalactan and the galactan associated with pectic materials were all degraded. The products were largely oligosaccharides, little free hexose or pentose being produced.

Starch. Fig. 6 shows the effect of enzymic degradation on the iodine-staining reaction of soluble starch and of waxy maize starch (amylopectin). The staining persisted to a point where $90 \%$ of the starch had been converted into glucose, indicating that $\alpha-(1 \rightarrow 4)$-linked glucose polymers capable of staining with iodine remained until a very late stage in the hydrolysis. Hence either a resistant dextrin was formed or else a stepwise hydrolysis proceeding from the ends of the polysaccharide chains and able to hydrolyse or to bypass branch points in these chains was taking place. The very close agreement between glucose released and the total reducing power of the digests (Fig. 7) further indicates the action of an exo-enzyme splitting off successive glucose residues along the substrate molecule. Since waxy maize starch was degraded faster than soluble starch, the degradation probably proceeded from the non-reducing ends of the polysaccharide chains, there being more such ends in amylopectin. The main features of the starch-degrading activity are therefore consistent with the action of a glucoamylase. It is possible that the combined action of $\beta$-amylase and maltase could 


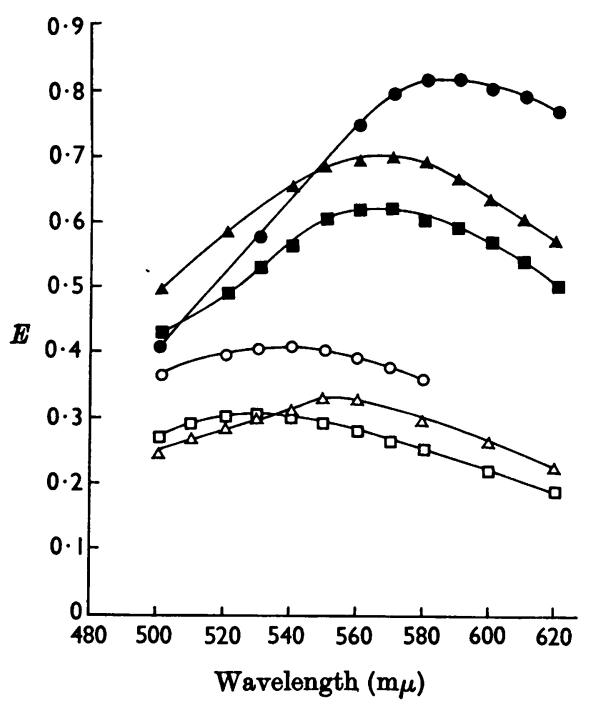

Fig. 6. Effect of amylase digestion on the iodine-staining reaction. The reaction was carried out as described in the text. Soluble starch: $\bullet, 0 \%$ conversion into glucose; $\boldsymbol{\Delta}$, $45 \%$ conversion into glucose; $\square, 60 \%$ conversion into glucose; amylopectin : $O, 0 \%$ conversion into glucose; $\Delta$, $66 \%$ conversion into glucose; $\square, 80 \%$ conversion into glucose.

produce a somewhat similar pattern of degradation. However, the weak maltase activity present in the culture filtrate was completely inhibited by $0.1 \mathrm{M}$ tris in acetate buffer, pH 5.0, whereas the rate of degradation of soluble starch was only decreased to about $40 \%$ of that of controls and glucose was still virtually the only product of starch hydrolysis. It is unlikely therefore that the maltase or a $\beta$ amylase is involved in a major way in the starch degradation.

Laminarin. This was rapidly degraded by culture filtrates from cellulose-, starch- or hemicellulose-grown cultures. A series of oligosaccharides was produced but glucose was the major product. Fig. 7 shows the production of glucose and the increase in total reducing power during the hydrolysis.

Pectin. The fungus failed to grow with pectin as sole carbon source, and with most other carbon sources pectinase activity was absent or weak. Cultures grown on malt extract were the best source of pectinase activity but even with this carbon source the activity was low. However, degradation of the pectic acid molecule seemed to occur by hydrolysis and galacturonic acid was detected on paper chromatograms (solvent system $A$ ) of the digest.

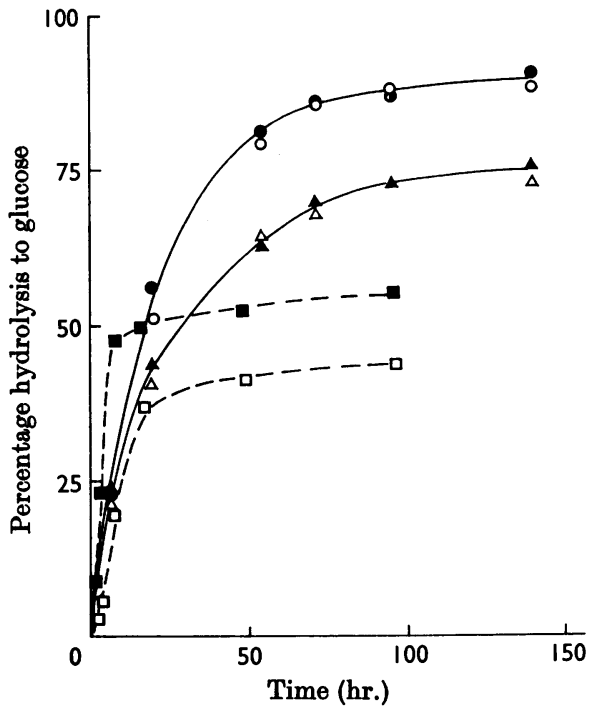

Fig. 7. Comparison of percentage hydrolysis to glucose as measured by the Nelson-Somogyi method and by the glucose-oxidase method for starch and laminarin. Soluble starch:, Nelson-Somogyi method; O, glucose-oxidase method; amylopectin: $\Delta$, Nelson-Somogyi method; $\Delta$, glucose-oxidase method; laminarin : $\square$, Nelson-Somogyi method; $\square$, glucose-oxidase method.

\section{DISCUSSION}

C. cerebella was capable of producing extracellular enzymes active against most of the components of wood other than lignin. Apart from the laminarinase, all the enzymes acting on polymeric substrates were adaptive and the exception was probably a special case. $\beta$ - $(1 \rightarrow 3)$-Glucanase activity is very common in fungal cultures. Reese \& Mandels (1959) detected it in 134 of the 140 fungi tested and showed that it was a constitutive enzyme. Chesters $\&$ Bull (1963) agreed with these findings and their list of fungi producing large amounts of this activity included several wood-destroying species. However, laminarin is not a naturally occurring carbon source for any of these fungi nor for C.cerebella, and it was probably degraded by an enzyme system the true substrate of which was a structurally related polysaccharide normally available to the fungus. Such polysaccharides occur in the fruit bodies of the wood-destroying fungi Poria cocos (Warsi \& Whelan, 1957)andPolyporusgiganteus (Bhavendam, Bouveng $\&$ Lindberg, 1964) and may represent structural or reserve carbohydrates in these fungi. $\beta-(1 \rightarrow 3)$ Glucans have also been found in the hyphal walls of some fungi (see Clarke \& Stone, 1963) and presumably have a structural function. Viscous extracellular glucans containing appreciable 
amounts of $\beta$-( $1 \rightarrow 3)$-linkages are produced by Plectonia occidentalis and Helotium species (Wallen, Rhodes \& Shulke, 1965a,b). If $C$. cerebella produced similar extracellular polysaccharides, the laminarinase activity, which was low in young cultures, may represent a later stage when the accumulated material was reabsorbed and metabolized. Alternatively, this activity may be associated with the lysis of older areas of mycelium, in which case the $\beta$ - $(1 \rightarrow 3)$-glucan would probably be a structural rather than a reserve polysaccharide. The laminarinase may therefore be a self-induced rather than a constitutive enzyme activity.

Cellulase activity has been ascribed to a single enzyme by Whitaker (1953), whereas others (e.g. Reese \& Levinson, 1952; Jermyn, 1952; Miller \& Blum, 1956; Petterson \& Porath, 1963; Selby, Maitland \& Thompson, 1963) have described multiple enzyme systems. The experiments described in the present paper were not designed to test for heterogeneity. However, the culture filtrates had little activity on lignified cellulosic materials and on the more native forms of cellulose, whereas the fungus in culture utilized all the types of cellulosic carbon sources supplied to it. This may be interpreted as evidence of heterogeneity, a factor essential in the degradation of native cellulose being firmly retained on the residual cellulose in the culture medium, or else being particularly labile and rapidly denatured. Alternatively, the failure of the culture filtrates to bring about the same degradation as the fungus may be a concentration effect, hydrolytic enzymes being secreted in high concentration at localized sites by the fungus and such high concentrations of enzyme, or of several enzymes acting together, being necessary for the degradation of the more native forms of cellulose.

The major starch-degrading enzyme appeared to be a glucoamylase. Similar enzymes have been described in other fungi (Phillips \& Caldwell, $1951 a, b$; Kerr, Cleveland \& Katzbeck, 1951 ; Pazur \& Ando, 1959; Tsujisaka, Fukumoto \& Yamamoto, 1958) and this may be a common type of starchdegrading system in fungi. Lyr (1959c) concluded that the principal amylolytic enzyme of wooddestroying fungi, including $C$. cerebella, was an $\alpha$-amylase. However, his method of assay, based on the production of reducing end groups from starch, would not distinguish between glucoamylase and $\alpha$-amylase unless the hydrolysis were allowed to proceed beyond $50 \%$ conversion into glucose.

The three glucose polymers, cellulose, starch and laminarin, were degraded in different ways. The pattern of hydrolysis products indicated that cellulose was degraded in a random and starch in a strictly stepwise manner. Laminarin occupied a position intermediate between cellulose and starch, the products of hydrolysis resulting either from the combined action of an endo-enzyme and a $\beta$ glucosidase or of an endo-enzyme capable also of degrading the laminarin-derived oligosaccharides to glucose.

Very little work has been done on the hemicellulose-degrading enzymes of wood-destroying fungi. Sorensen (1952) has described the action of an inducible xylanase from Chaetomium globosum, a soft-rot fungus, on wheat-straw xylan. Xylose and a series of xylo-oligosaccharides, arabinose in small amounts and a resistant polysaccharide were produced. More than one enzyme appeared to be involved in the degradation and at least one of these acted randomly on the xylan main chain. Coniophora xylanase gave similar products when acting on spruce xylan but little xylose or arabinose was released; here too a random depolymerization seemed to occur. Other enzymes present in the hemicellulase complex were capable of degrading spruce glucomannan to a complex mixture of oligosaccharides, presumably by a process of random hydrolysis, and of producing a slow and somewhat limited degradation of larch arabinogalactan.

Contrary to Lyr $(1959 a, b, c, 1960,1962,1963 a, b)$ only the laminarinase $[\beta-(1 \rightarrow 3)$-glucanase $]$ was found to be constitutive; cellulase, hemicellulase and amylase were inducible. However, Lyr incorporated malt extract in all his culture media and the present work has shown that this induces the production of pectinase, hemicellulase and massive amounts of amylase. Thus the differences between Lyr's results and those reported in the present work may be ascribed to the presence of malt extract in his media.

This paper is published by permission of the Ministry of Technology.

\section{REFERENCES}

Apenitis, A., Erdtman, H. \& Leopold, B. (1951). Svensk kem. Tidskr. 63, 195.

Armstrong, F. H. \& Savory, J. G. (1959). Holzforschung, 13, 84.

Bhavendam, V. P., Bouveng, H. O. \& Lindberg, B. (1964). Acta chem. scand. 18, 504.

Bose, S. R. \& Sarkar, S. N. (1937). Proc. Roy. Soc. B, 123, 193.

Chesters, C. G. C. \& Bull, A. T. (1963). Biochem. J. 86, 28.

Clarke, A. E. \& Stone, B. A. (1963). Rev. pure appl. Chem. $13,134$.

Dahlquist, A. (1961). Biochem. J. 80, 547.

Higa, H. H., O'Neill, R. D. \& Jennison, M. W. (1956). J. Bact. 71, 382.

Huggett, A. St G. \& Nixon, D. A. (1957). Lancet, 368.

Jermyn, M. A. (1952). Aust. J. sci. Res. 5B, 433.

Jermyn, M. A. (1957). Aust. J. Chem. 10, 53.

Jones, J. K. N., Wise, L. E. \& Jappe, J. P.(1956). T.A.P.P.I. $39,139$. 
Kerr, R. W., Cleveland, F. C. \& Katzbeck, W. J. (1951). $J$. Amer. chem. Soc. 73, 3916.

Kubiak, M. \& Kerner, G. (1963). Dłev. V'́sk. 4, 181.

Lowry, O. H., Rosebrough, N. J., Farr, A. L. \& Randall, R. J. (1951). J. biol. Chem. 193, 265.

Lutz, L. (1930). C.R. Acad. Sci., Paris, 190, 892.

Lyr, H. (1959a). Arch. Mikrobiol. 33, 266.

Lyr, H. (1959b). Arch. Mikrobiol. 34, 189.

Lyr, H. (1959c). Arch. Mikrobiol. 34, 418.

Lyr, H. (1960). Arch. Mikrobiol. 35, 258.

Lyr, H. (1962). In Holzzerstorung durch Pilze (int. Symp.), Eberswalde, p. 111. Berlin: Akademie-Verlag.

Lyr, H. (1963a). Z. allg. Mikrobiol. 3, 25.

Lyr, H. (1963b). Arch. Mikrobiol. 45, 198.

Meier, H. (1958). Acta chem. scand. $12,144$.

Miller, G. L. \& Blum, R. (1956). J. biol. Chem. 218, 131.

Nelson, N. (1944). J. biol. Chem. 153, 375.

Pazur, J. H. \& Ando, T. (1959). J. biol. Chem. 234, 1966.

Petterson, G. \& Porath, J. (1963). Biochim. biophys. Acta, 67, 9.

Phillips, L. L. \& Caldwell, M. L. (1951a). J. Amer. chem. Soc. 73, 3559.

Phillips, L. L. \& Caldwell, M. L. (1951b). J. Amer. chem. Soc. 73, 3563.

Reese, E. T. \& Levinson, H. S. (1952). Physiol. Plant.5, 345.
Reese, E. T. \& Mandels, M. (1959). Canad. J. Microbiol. 5, 173.

Rypácek, V. (1960). Acta agrobot. 8, 53.

Seifert, K. (1962). Holzforschung, 16, 102.

Selby, K., Maitland, C. C. \& Thompson, K. V. A. (1963). Biochem. J. 88, 288.

Sison, B. C., Schubert, W. J. \& Nord, F. F. (1957). Arch. Biochem. Biophys. 68, 502.

Sison, B. C., Schubert, W. J. \& Nord, F. F. (1958). Arch. Biochem. Biophys. 75, 260.

Somogyi, M. (1952). J. biol. Chem. 195, 19.

Sorensen, H. (1952). Physiol. Plant. 5, 183.

Trevelyan, W. E., Procter, D. P. \& Harrison, J. S. (1950). Nature, Lond., 166, 444.

Tsujisaka, Y., Fukumoto, J. \& Yamamoto, T. (1958). Nature, Lond., 181, 770.

Wallen, L. L., Rhodes, R. A. \& Shulke, H. R. (1965a). Appl. Microbiol. 13, 267.

Wallen, L. L., Rhodes, R. A. \& Shulke, H. R. (1965b). Appl. Microbiol. 13, 272.

Warsi, S. A. \& Whelan, W. J. (1957). Chem. \& Ind. p. 1573. Whitaker, D. R. (1953). Arch. Biochem. Biophys. 43, 253.

Wilson, C. M. (1959). Analyt. Chem. 31, 1199.

Wise, L. E., Murphy, M. \& D'Addieco, A. A. (1946). Paper Tr. J. 122, 35. 